Reconstructing The Nature of Inclusive School System in Primary School to-

Strengthening Inclusive Society

Submitted: 10 September 2019, Accepted: 26 December 2019

AL-BIDAYAH: Jurnal Pendidikan Dasar Islam

ISSN: 2085-0034 (print), ISSN: 2549-3388 (online)

\title{
RECONSTRUCTING THE NATURE OF INCLUSIVE SCHOOL SYSTEM IN PRIMARY SCHOOL TO STRENGTHENING INCLUSIVE SOCIETY
}

\author{
Zidniyati \\ Institut Agama Islam Ibrahimy Genteng Banyuwangi \\ E-mail: taravizidni@gmail.com
}

\begin{abstract}
This paper contains theoretical discussions about the nature of inclusive education and the implications needed in the practice of inclusive school systems, especially at the elementary school level. The formulation of the problem raised in this study is: What is the nature of the implementation of the inclusive education system in elementary schools? What are some examples of inclusive education practices so far? What is the relationship between inclusive education and value education in schools? How can inclusive education strengthen inclusive communities? What are the implications of implementing the inclusive education system in elementary schools? The five questions will be answered by a discussion approach on various theories that have been raised by many experts and by looking at the practices of inclusive education in several developing countries and developing countries. This research used literature review methods. The findings in this study are that inclusive education will be realized in an inclusive community environment that holds fast to the values of mutual acceptance, mutual respect, and mutual love for one another. In other words, inclusive education means preparing all members of the inclusive community in schools for inclusive communities.
\end{abstract}

Keywords: inclusive school system, elementary school, inclusive society.

\section{INTRODUCTION}

Development in Indonesia, which has been oriented towards a growth paradigm, has indeed succeeded in achieving high economic growth but has brought various negative impacts, including exclusivity, environmental damage, depreciation of natural resources, and social inequality, including in the education sector for vulnerable people, especially children schools that have special needs. With an education system that only offers scholarships for high achieving children, scholarships for children from economically disadvantaged but still high achievers, there is practically no free space for learning opportunities for children who have not performed well, especially those from underprivileged backgrounds, even those from an economic background are capable, but the child with special needs has difficulty finding schools that are willing to accept it for learning with children who do not have special needs. This reality is a problem for the social justice of the vulnerable, especially school-age children who have special needs. 
Attention for persons with disabilities is critical because the numbers are relatively large. Globally, people with disabilities make up around $15 \%$ of the world's population of more than one billion people. Around $82 \%$ of people with disabilities live in developing countries and are below the poverty line and experience limited access to health, education, training, and decent work. It is estimated that $10 \%$ of Indonesia's population has a disability or more than 24 million people. Persons with disabilities are marginalized and vulnerable people. Persons with disabilities are also often socially isolated and suffer discrimination in access to health and other services, such as education and employment. ${ }^{1}$

The results of the Basic Health Research (Riskesdas) conducted in 2013 showed that the number of people with disabilities reached $11 \%$ of the total population aged 15 years and over. The 2010 Population Census program conducted by the Central Statistics Agency (BPS) showed a figure of $4.74 \%$ or $9,046,000$ inhabitants of the population aged ten years and over. Other data, namely the results of the National Socio-Economic Survey (Susenas) conducted by BPS in 2012, showed the number of people with disabilities was $6,008,661$ people. Of this number, the majority of people with disabilities are double disabilities, followed by the blind. The 2012 Susenas results show there are around 2,401,592 people who have multiple disabilities; and around 1,780,200 people with visual impairments. The rest are deaf-speech, intellectual/intellectual disabilities, bodily disabilities, and persons with disabilities who have difficulty taking care of themselves. A recent survey conducted by BPS through the Inter-Census Population Survey (SUPAS) in 2015 showed that the number of people with disabilities reached 21.5 million people or $8.56 \%$ of the total population of Indonesia. ${ }^{2}$

If more development is oriented towards economic growth, with Gross Domestic Product (GDP) as the primary measure, while social welfare and justice are not yet a top priority, then there is homework for the world of education that must be resolved immediately. Apart from the numbers, Azra $^{3}$ said that people with disabilities, in general

\footnotetext{
${ }^{1}$ Sad Dian Utomo, Fajri Nur Syamsi, Ermy Ardhyanti, \& Fitria. Policy Paper: Mewujudkan Pembangunan Inklusif Disabilitas: Rekomendasi Kebijakan untuk Penyusunan RPJMN 2020-2024. (2018). http://pattiro.org/2018/11/policy-paper-mewujudkan-pembangunan-inklusif-disabilitas-rekomendasikebijakan-untuk-penyusunan-rpjmn-2020-2024/.

${ }^{2}$ Ibid.

${ }^{3}$ Novita Anggraeni dan Sad Dian Utomo. Pelayanan Publik Bagi Disabilitas: Kajian Praktik Baik dan Inovasi dari Mitra Program Peduli Pilar Disabilitas. Fase 1 (tahun 2015-2016) di Lima Provinsi pada Sektor Pelayanan Publik. (Jakarta: PATTIRO Pusat Telaah dan Informasi Regional, 2018). http://pattiro.org/2018/06/pelayanan-publik-bagi-disabilitas-kajian-praktik-baik-dan-inovasi-dari-mitraprogram-peduli-pilar-disabilitas-fase-1-tahun-2015-2016-di-lima-provinsi-pada-sektor-pelayanan-publik/.
} 
are victims of misconceptions, stereotypes, labels, and prejudices that result in discrimination, exclusion, wrong treatment, and deprivation of the right to education, equivalent work, and services. Research by the Australian Government in collaboration with Indonesia shows that people with disabilities/disabilities in Indonesia have lower levels of education, more inadequate access to health, less access to capital/economy, and less access to public services than people without disabilities.

The growth paradigm that develops in Indonesia turns out to create social exclusion, which leads to the difficulty of vulnerable groups involved in the development process. Thus, Indonesia needs a paradigm shift from economic-oriented development to the output of pursuing economic growth (exclusive development), towards an inclusive development paradigm that aims to prosper all levels of society. This inclusive development is a development concept that seeks to give rights to marginalized groups (including those with disabilities, the poor, and minorities) in the development process.

The meaning of inclusive development is the process of ensuring that all marginalized community groups can be fully involved in the development process (International Disability and Development Consortium). Inclusive development in Indonesia seems to be far from expectations, even though there have been efforts to make it happen. Based on the 2017 Inclusive Growth and Development Index 2017 released by the World Economic Forum in early 2017, Indonesia ranked 22 out of 79 developing countries with a value of 4.29. Indonesia is still below Thailand (12), China (15), and Malaysia (16). The Inclusive Development Index (IDI) is an economic indicator that describes the equitable growth and economic development in a country. There are 3 indicators used in this index, namely growth and development, inclusion and intergenerational equity, and sustainability (intergenerational justice and sustainability). ${ }^{4}$

The indicators above show that Indonesia has a severe problem of inequality. In other words, development in Indonesia is still far from being inclusive of development. Whereas national development itself aims to realize sustainable and inclusive economic growth, that is growth that meets the needs of the current generation without reducing the ability of future generations, distributed in various regions, and can reduce income inequality.

\footnotetext{
${ }^{4}$ World Economic Forum. The Inclusive Growth and Development Report (2017).
} 
The concept of inclusive development is in line with the concept of social justice enshrined in the Five Principles of Pancasila, namely Social Justice for All Indonesian People, and the fourth paragraph Opening of the 1945 Constitution, which reads: protecting all nations and all spilled Indonesian blood, advancing public welfare, educating the nation's life, and participate in carrying out world order based on independence, eternal peace, and social justice. The state has to provide opportunities for all citizens, including those with special needs.

The importance of sustainable development is getting a global reaction with the declaration of the Sustainable Development Goals/SDGs a Sustainable Development Goals that will be applied until 2030. SDGs are a follow-up program of the Millennium Development Goals / MDGs or Millennium Development Goals that have been implemented within 15 years (2000 -2015). The fourth objective of the SDGs is very much by this research study, which is "Ensuring Quality of Inclusive and Even Education and Increasing Opportunities for All-Life Learning for All."

In another research study, conducted by Rohidin Sudarno and Sad Dian Utomo ${ }^{5}$, stated that currently, there are still many things that cause a comprehensive disability data not yet available and can be used by all sectors in development. The data collection problem will have an impact on the fulfillment of essential public services, including education services. Among one of the obstacles is the family of children/people with special needs feel ashamed to provide data that one of their family members has particular needs/disability. This problem happens because of the negative stigma in developing societies regarding people with disabilities. Let us look at an inclusive education provider school that has been involved in the implementation process, which is also affected by various factors, as identified in several studies above. The root of the problem of implementing inclusive education in schools is the difficulty of schools building strong relationships with parents and policymakers in creating an atmosphere of inclusion that is certainly child-friendly. Every year there are always children with special needs who move from other schools to this school with motivation to look for patterns of child-friendly education, or with motivation, other schools do not accept children with special needs.

\footnotetext{
${ }^{5}$ Rohidin Sudarno dan Sad Dian Utomo. Inovasi Pendataan Disabilitas: Inovasi dan Praktik Baik Mitra Program Peduli Disabilitas Fase 1 di Enam Provinsi. (Jakarta: PATTIRO Pusat Telaah dan Informasi Regional, 2018). http://pattiro.org/2018/06/inovasi-pendataan-disabilitas-kajian-dan-praktikbaik-mitra-program-peduli-disabilitas-fase-1-di-enam-provinsi/.
} 
Looking at various phenomena that have occurred during the last 7 (seven) years since Tabita Puri Elementary School, usually called Sekolah Dasar (SD) Tabita Puri, was established, things have been repeated throughout the year. The repetition in question is the transfer of students from other schools to Tabita Puri Elementary School based on the reasons: the difficulty of students avoiding bullying situations, and the motivation of parents to enroll their children in this school is because they expect a pattern of intensive care and assistance from class teachers.

SD Tabita Puri is a private school that has tried to implement an inclusive education system since the first year the school was established in 2012. Although its inclusive education practices are still experiencing various obstacles, however, this school is classified as consistent in the implementation of the inclusive school system. ${ }^{6}$ This school is located in a sub-district in Banyuwangi Regency. No more than 20 students fill each class level with 2 teachers. The school hours applied are quite long, which is around 8 hours, because school hours start at 07.30-15.30 WIB. Some schools in the same subdistrict prefer to apply the learning system as usual. Administrators of these schools tend to choose to implement a regular school system rather than an inclusive school system.

The regular school system referred to in this study is a school system that does not accept children with special needs as students. Some information submitted by school principals in Genteng Subdistrict, Banyuwangi Regency, why they prefer to implement the regular school system are: avoiding the low average of the national exam results that must be followed by all grade 6 students; the absence of a teacher who can accompany students with special needs, or there is one individual assistant teacher, but the teacher's skills are not sufficient to accompany students with special needs. Schools with this conventional system are schools that have no fewer than 20 students, can even reach 35 students in one class, and there are 2 to 6 classes at each level. Because each class is filled with regular students, who do not have special needs (according to a cursory observation of teachers in regular schools), there is usually only one teacher per class consisting of 20 to 35 students. The level of difficulty experienced by a teacher in a regular class can already be imagined. One of the difficulties is the emergence of unexpected student

6 Zidniyati, "Penguatan Pendidikan Karakter di Sekolah Dasar di Era Revolusi Industri 4.0." Tarbiyatuna: Kajian Pendidikan Islam 3, no. 1 (2019): 39-55. Available at http://ejournal.iaiibrahimy.ac.id/index.php/tarbiyatuna/article/view/199. Date Accessed September $6^{\text {th }} 2019$ at 10.11. a.m. 
behavior. For example, violent behavior towards classmates. Most of the deviant behavior that contains violence arises because students (perpetrators) have not been able or have difficulty in interacting with friends. These cases often occur and are one of the reasons parents move their children to inclusive schools.

In this paper review, the author explains the nature of the inclusive school system to the implications needed in the application of inclusive education in primary schools. The main focus of this study is to re-examine the need for value education in building an inclusive community in schools with an inclusive system. Judging from the various phenomena that occur, the following questions are formulated as questions to be answered through theoretical studies and based on observations of the practices of the inclusive school system. First, what is the nature of the implementation of the inclusive education system in elementary schools? Second, what are some examples of inclusive education practices so far? Third, what is the relationship between inclusive education and value education in schools? Fourth, how can inclusive education strengthen inclusive communities? Fifth, what are the implications of implementing the inclusive education system in elementary schools?

\section{RESEARCH METHODS}

The method used to achieve the objectives of this paper study is a literature study with additional observations of inclusive education practices in several schools in Yogyakarta and Banyuwangi. In Yogyakarta involving five private primary schools, and in Banyuwangi involving one public primary school. Data collected from these schools was carried out through interviews and direct observations. Interviews were conducted with school principals and teachers. While observations were made during the first hour of school until after school hours in each class. The time for conducting interviews and observations is conducted from November 2018 to June 2019.

\section{RESULT AND DISCUSSION}

Here is describe the result of the study and discussion of various theories concerning inclusive education, inclusive education linkages with the value of education, the environment required to implement inclusive education system, as well as the implications of the implementation of the inclusive education system. 


\section{The Nature of Inclusive Education}

Before 1987 the term inclusive education was still rarely used among educators and individual education observers. ${ }^{7}$ The term integration is used more often. Proponents of inclusion argue that inclusive schools are schools that accept all children. The central policies, practices, and reasons for inclusive schools involve everyone and ensure that everyone has one another. Conversely, the emphasis in integration is on the physical movement of children from one place to another without the simultaneous expectations of changes needed by public schools: for too long, integration rests on what Lipsky and Gartner in Thomas $^{8}$ refer to as a 'readiness" model. In other words, children and adolescents must prove their readiness for integrated arrangements, rather than for specific arrangements expected to prove their readiness to accept. It is this assumption of acceptance that is the hallmark of inclusion. This explanation confirms that acceptance becomes a necessity that is entrenched in the creation of an inclusive environment.

Inclusion is the opposite of exclusion. Carrington and Macarthur quote Booth's opinion by stating, "Exclusion can be understood as a process that occurs when students are denied or have reduced access to the culture and curricula of their local school." 9 Exclusion or exclusion can be understood as a process that occurs when students attend school but are denied or have reduced access to join their local school culture and curriculum. In such cases, teachers are needed to stop situations that are uncomfortable for children who are excluded by shifting the situation of exclusion to a whole situation. ${ }^{10}$ Kearney reinforced Booth's opinion by saying, "Whenever students are denied access to the culture and curricula of mainstream schools, they are devalued. ${ }^{11}$ Whenever students are not given access to the culture and curriculum of public schools, they will experience devaluation. Devalued can lead a child or adult human to have feelings of isolation and

7 Thomas, G. "Inclusive schools for an inclusive society". British Journal of Special Education 24, no. 3 (1997): 103-107. Available at https://onlinelibrary.wiley.com/doi/abs/10.1111/1467-8527.00024. Date accessed on September, $5^{\text {th }} 2019$ at 11.18 p.m.

${ }^{8}$ Ibid.

${ }^{9}$ Carrington, S. B., \& Macarthur, J. Teaching in inclusive school communities. (John Wiley \& Sons Inc, 2012). p. 24.

${ }^{10}$ Ibid.

11 Kearney, A. "Barriers to school inclusion: An investigation into the exclusion of disabled students from and within New Zealand schools." Unpublished thesis (Massey University: Palmerston North, New Zealand, 2009). Available at https://scholar.google.co.id/scholar?hl=id\&as_sdt=2005\&sciodt $=0 \% 2 C 5 \&$ cites $=5758551630393361173$ $\&$ scipsc $=\& q=$ kearney $\% 2 \mathrm{C}+\mathrm{A}+$ barrier+to + school+inclusion $\&$ oq $=$ Date Accessed on September $5^{\text {th }} 2019$ at 5.03 a.m. 
isolation, and more sadly, this kind of feeling can enable one to make that feeling as a reason to commit a crime and many others. ${ }^{12}$

The basic premise of inclusive education is that all children are included in school, and all children can participate and learn meaningfully in school. While inclusive education is concerned with making schools more responsive to all students, students with disabilities are reported as the largest group of students excluded and marginalized from quality education in the world today. ${ }^{13}$ Therefore, students with disabilities experience many obstacles to their attendance, participation, and learning in school, and little is known about the specific nature of these barriers. Following this kind of exclusion phenomenon, schools began to emerge with a segregation system, where students with special learning needs. The suitability of separate education systems for students with disabilities begins to be challenged, first from the perspective of human rights and effectiveness, then finally, from challenges to a special educational knowledge base and social, cultural and political reasons for its existence. ${ }^{14}$

Slee also proposed an overview of inclusive education. ${ }^{15}$ Slee described inclusive education as a project of ethics and political position that challenged values to be treated hierarchically for certain societies that considered some societies more valuable than others. Inclusion is not something that must be done for certain groups of children or young people. Slee emphasized that inclusion is something we all must do for all of us. Slee said, "In this respect, inclusive education invites us to think about the nature of the world we live in, in the world that we prefer and our role in shaping both of those worlds." In this case, inclusive education invites us to think about the nature of the world we live in, in the world we like, and our role in shaping the two worlds. Even Slee emphasized that the schooling process is a training in democracy, and inclusion is a prerequisite for democratic education.

Salend provides a useful definition of inclusive education, as follows: ${ }^{16}$

"Inclusion is a philosophy that brings students, families, educators, and community members together to create schools based on acceptance, belonging, and community.

\footnotetext{
${ }^{12}$ Ibid.

13 Ibid.

${ }^{14}$ Ibid.

15 Carrington, S. B., \& Macarthur, J. Teaching in inclusive school communities. (John Wiley \& Sons Inc, 2012). p. 24.

${ }^{16}$ Ainscow, M., Slee, R. \& Best, M. "Editorial: the Salamanca Statement: 25 years" International Journal of Inclusive Education 23 (2019):7-8, 671-676, DOI: 10.1080/13603116.2019.1622800.
} 
Inclusionary schools welcome, acknowledge, affirm, and celebrate the values of all learners by educating them together in high quality, age-appropriate general education classes in their neighborhood schools."

Based on these definitions, Hornby points out that inclusive education is characterized by: (1) the philosophy of acceptance and ownership in a community; (2) student philosophy, family, educators, and community collaboration; (3) celebrate diversity and values that are believed by all students; (4) valuing educating learners in high quality schools; (5) valuing educating learners with their peers; (6) valuing educating learners in public schools; (7) valuing educating learners in schools in their local communities.

Meanwhile, Booth and Ainscow assert that inclusion is about minimizing all obstacles in education for all students. ${ }^{17}$ Inclusion starts with the recognition of differences between students. Based on various ideas, we can conclude inclusive education. Inclusive education is an education system for all children who demand the creation of a culture of acceptance and ownership of one another, which involves the collaboration and participation of all students, teachers, parents, as well as the community and is based on the idea that schooling is a training ground to be part of a democratic society.

The inclusion concept in this study is different from the inclusion concept issued by UNESCO. The concept of inclusion in this study is a transformation process whose idea is to eliminate the selective process of education and negative attitudes or responses to diversity in debates with race, economic status, social class, relationships, religion, gender, language, and outcomes, and which addresses disability. Thus, the inclusion in this study is not as proposed in the sense of inclusion, which also gives freedom to the discussion in the writings of Azorin and Ainscow in citing the inclusive conception of inclusive transformative by UNESCO. ${ }^{18}$

Concerning the concept of inclusion proposed by UNESCO, it is necessary to give limitations in this study. The concept of inclusion, according to UNESCO is an idea to eliminate the expensive educational process and negative attitudes or responses to diversity in debates with race, economic status, social class, sexual orientation, ethnicity,

\footnotetext{
${ }^{17}$ Boot, T. \& Ainscow, M. Index for inclusion developing learning and participation in schools. (Bristol (England): Centre for Studies on Inclusive Education, 2002).

18 Cecilia Azorín \& Mel Ainscow, "Guiding Schools on Their Journey Towards Inclusion" International Journal of Inclusive Education (2018), DOI: 10.1080/13603116.2018.1450900.
} 
religion, gender, language, and combinations, and those related to disability. In this study, it must be stressed that agreement on the concept of inclusion does not mean giving freedom of sexual orientation, because freedom of sexual orientation is contrary to norms in Indonesia. The meaning of inclusion applied in this study refers to the philosophy that humanizes students, both those with special needs and those without special needs can learn together and form a community of mutual respect.

\section{The Practice of Inclusive Education So far}

What are the practices of inclusive education so far? The following will be discussed about inclusion practices in elementary schools. However beforehand, let us look at the grand design of holding inclusions in Indonesia. In 2019-2024, we will then see the grand design of the inclusion in Indonesia.

In the 2017-2021 Inclusive Education Program Roadmap as a form of implementation of Law Number 8 of 2016 concerning Persons with Disabilities, the implementation of inclusive education is carried out in 3 stages: the Socialization Phase (2017-2018) with the target of equalizing perception and socialization, the Pilot Phase ( 2019) with the target of changing the attitudes of the education and community units, the Strengthening Phase (2020) with the target of expanding and improving service quality, and the Implementation Stage (2021) with the target of implementation at the district/city and national level. However, currently, there are only 29,317 inclusive organizing schools throughout Indonesia, ranging from elementary, junior high, high school, and vocational school. ${ }^{19}$ This program means that only around $11 \%$ of schools in Indonesia have implemented inclusive education, while on the road map, it is targeted that by 2021 all schools will be implementing inclusive education. This condition is the basis for consideration of conducting a review of the Inclusive Education Road Map to suit the conditions with the duration of the year starting in 2019 until 2024.

Let us look at inclusion practices in five private schools in Yogyakarta. The first school. In this first school, there is an average of 20 to 25 students in each class and 2 of them are students with special needs. This school has provided one primary teacher, one assistant teacher, and two accompanying teachers for students with special needs. So that in each class there are 4 teachers. Entirely served by every student in each class. This school has a total of no less than 600 students because each level has several classes. This

\footnotetext{
${ }^{19}$ Dapodik, as of January, $31^{\text {st }} 2019$.
} 
school also has 1 teacher as the inclusion coordinator. The task of this coordinator is to coordinate all matters related to the curriculum and activities of all students with special needs in this school. The school also has a psychologist who is always available at school to conduct therapy and special treatment for students in need. All students with special needs are included in the TOP (Talent Optimizing Program) program. A program specifically for students with special needs. The term TOP is embedded in special assistant teachers and students with special needs. This program illustrates the effort to change the term child with special needs to be a TOP child. Sounds very beautiful. This program is exemplary. All TOP students study with regular students in the same class, only on 1 hour on certain days, they will join the Pull out the program. Usually, in this Pull-out program, TOP students take part in life skills learning, such as how to brew tea, pour tea into the cup provided, and drink tea while chatting with other TOP students accompanied by TOP teachers. The types of special needs of TOP students are diverse, and some have Down syndrome, mental retardation, cerebral palsy, autism, and other behavioral disorders. All activities for TOP students are recorded. This school prepares the ILP (Individual Learning Program) for every TOP student. ILP will be evaluated regularly.

The second school, this school has 20 to 25 students in each class, and 2 to 10 students with special needs in it. This school has a total student population of around 300 students. Actually the school has made a mistake because it puts ten students in need in one class, so the teacher also has difficulty in handling them. Fortunately this error has been addressed by the addition of two special teacher assistants. Each class is provided by one class teacher and one assistant teacher. The school also has one teacher coordinator for the inclusion program. The school also has consultants and psychologists who will regularly visit the school at least twice a week. ILP (Individual Learning Program) is prepared periodically and regularly evaluated. The form of intervention by psychologists varies according to the needs of students. Types of student needs include autism, ADHD, slow learners, and other behavior disorders that are classified as mild to moderate, there are no students with specific types of classified as severe. Teachers in this school routinely attend training held by the local education office in collaboration with universities in Yogyakarta.

The third school, this school has an average of 3 to 15 students in each class, with one to two class teachers. In every class, there are not always students with special needs. 
The number of students is indeed not as much as the second and first schools. Nevertheless, the preparation of ILP (Individual Learning Programs) and efforts to identify student needs are done very well and routinely. Psychologists are only involved at certain times, not routinely because, indeed when the research is conducted, students with special needs do not need special intervention from a psychologist because they are categorized as mild special needs.

The fourth school, this school has students up to thousands. Each class consists of 25 to 32 students. Each class has 1 class teacher and 1 assistant teacher. This school does not accept students with special needs. The fifth school, this school has students in every class of 7 to 15 students. The teacher provided one class teacher. This school also does not accept students with special needs. The sixth school, Tabita Puri Elementary School was the last research location. In this school, there is an average of 12 to 22 students in each class, two of whom are students with special needs. There is one class teacher and one assistant teacher in each class. This school collaborates with a team of therapists who come every day to conduct therapy to students with special needs. The duration of therapy is done in 1 hour for one student with special needs, housed in one room. Psychologists only visit 2 times in 1 semester. Every parent or teacher who wants to consult will make time arrangements with the psychologist.

The following are some of the same things that happened to the six schools: first, the school compiles its questions and activities used for progress evaluation every three months and six months. However, because the local department requires all schools to take semester exams, all schools must take it. Obstacles occur when students with special needs with intellectual disabilities must also take an exam. Usually, the accompanying teacher will provide assistance so the student can take the exam, but many complete the exam with an empty answer sheet because the difficulty level is indeed unable to be solved due to the type of student intellectual barrier.

Second, the results of psychological observation are often rejected by parents. Usually parents feel that their children do not experience any obstacles, so that rejection often occurs. Usually, the school will provide an opportunity for parents to seek second opinions by making psychological observations for their children to other psychologists. Third, the sixth school has difficulty in finding secondary schools for students with special needs who have completed learning for 6 years. This is because the majority of junior high 
schools around SD Tabita Puri refuse students with special needs. Fourth, all schools studied developed a culture of value education. All the students play together in school.

Looking at the practices of education by practitioners in the 6 private schools, it appears that each school has a different way of assisting students. Schools that are implementing inclusion also show a variety of ways of assisting students with special needs. The examination system from the local education office, left homework for the inclusion organizer because the level of difficulty of the questions did not match the type of student's specificity.

\section{Inclusive Education to Strengthen Inclusive Community}

There is one reference compiled by Booth and Ainscow. ${ }^{20}$ This reference is known as the Index for Inclusion. Booth and Ainscow emphasize that inclusion is often associated with students who have disabilities or students who are considered "having special educational needs." However, in the Index, inclusion is about the education of all children and adolescents. This index offers schools a series of processes that support self-review and development, which refers to the views of staff, governors, students and parents/caregivers, and other members of the surrounding community. This index involves a detailed examination of how barriers to learning and participation can be reduced for each student. Furthermore, Booth and Ainscow detail that inclusion in education involves the following: (1) assess all students and staff equally; (2) increase student participation in and reduce their exclusion from the culture, curriculum, and local school community; (3) restructuring culture, policies, and practices in schools so that they respond to the diversity of students in the region; (4) reducing barriers to learning and participation for all students, not only those who have limitations or those who are categorized as "having special educational needs"; (5) learn from efforts to overcome specific barriers to student access and participation to make changes for the broader benefit of students; (6) see differences between students as resources to support learning, rather than problems that must be overcome; (7) recognizing the rights of students to get an education in their area; (8) improving schools for staff and students; (9) emphasizing the role of schools in building communities and developing values, as well as in improving achievement; (10) fostering

${ }^{20}$ Boot, T. \& Ainscow, M. Index for inclusion developing learning and participation in schools. (Bristol (England): Centre for Studies on Inclusive Education, 2002). 
mutually supportive relationships between schools and the community; (11) recognizing that inclusion in education is one aspect of inclusion in society.

Inclusion is about making schools support and stimulate places for staff and students. It is about building a community that encourages and celebrates their achievements. However, inclusion is also about building a wider community. Schools can work with other institutions and with communities to improve educational opportunities and social conditions in their area.

There is the firmness expressed by Ainscow and Miles when highlighting the challenges faced by education. ${ }^{21}$ The challenge is to ensure that all children complete primary education, which is a crucial step to reduce poverty and human deprivation in what Hulme calls the world's biggest promise in the form of the Millennium Development Goals. ${ }^{22}$ Meanwhile, in rich countries - regardless of available resources - many young people leave school without valuable qualifications, others are placed in various forms of special provision away from the general education experience, and some only choose to drop out of school because the lessons seem not relevant for their lives.

There is evidence of increasing interest in the idea of inclusive education for facing the challenge. However, there is confusion about what actions need to be taken to advance policies and practices going forward. In some countries, inclusive education is still considered an approach to serving children with disabilities in the general education environment. Nevertheless internationally, this is increasingly seen more broadly as a reform that supports and welcomes diversity among all students. This idea assumes that the goal of inclusive education is to eliminate social exclusion that is a consequence of attitudes and responses to diversity in race, social class, ethnicity, religion, gender, and ability. ${ }^{23}$ As such, inclusive education starts with the belief that education is a very basic human right and a foundation for a more just society that views supporting and welcoming

\footnotetext{
${ }^{21}$ Ainscow, M., \& Miles, S. "Making Education for All inclusive: where next?" Prospects, 38, no. $1 \quad$ (2008): 15-34. Available at https://scholar.google.co.id/scholar?hl=id\&as_sdt=0\%2C5\&q=ainscow+\%26+miles\&btnG=. Data Accessed on September $5^{\text {th }} 2019$ at 5.13 a.m.

${ }^{22}$ Hornby, Garry. Inclusive special education:evidence-based practices for children with special needs and disabilities. (New York: Springer, 2014).

${ }^{23}$ Zidniyati, "The implementation of values Comprehensive approach in developing character in an elementary school in banyuwangi (An Observational Report)" Proceeding International Conference on Islamic Education (ICIED) 2, no. 1 (2017): 286-298. Available at https://scholar.google.co.id/scholar?hl=id\&as_sdt=0\%2C5\&q=zidniyati\&btnG= Date Accessed September $6^{\text {th }} 2019$ at 10.00 a.m.
} 
diversity among all learners to eliminate social exclusion that is a consequence of attitudes and responses to diversity in race, social class, ethnicity, religion, gender and ability, and this goal is to prepare a generation that is ready to be part of an inclusive society.

\section{The Linkage between Inclusive Education and Values Education in Schools}

As stated by Salend, ${ }^{24}$ inclusive education is closely related to the philosophy of acceptance and a sense of mutual belonging that exists in students, teachers, parents, and the community. As Garry states that an inclusive society needs temporary Slee asserting that the schooling process is a training in democracy, inclusion then is a prerequisite of democratic education. ${ }^{25}$ Booth and Ainscow assert that inclusion is about minimizing all obstacles in education for all students. ${ }^{26}$ Inclusion starts with the recognition of differences between students. Based on this, there are values needed to be used as guidelines in inclusive communities, and in schools with an inclusive system, of course. Carrington and Macharthur stated that values are based on the commitment to critical values and principles that are constantly being questioned, discussed, and developed within and between schools. Booth describes values as fundamental guidelines that provide direction and support action towards others. ${ }^{27}$ In developing a value framework, schools make statements about how their communities will live together and educate one another.

There is no doubt that the population of children and adolescents who are not disaggregated, diverse, and schools will produce schools that are more sensitive and more human. Moreover, that will produce a generation of young people who are more tolerant and accept differences. In inclusive schools, all will develop. ${ }^{28}$

Ainscow et.al described a set of values that are the basis for action when working towards inclusion. ${ }^{29}$ Some, such as the sustainability and assessment of the international

\footnotetext{
${ }^{24}$ Hornby, Garry. Inclusive special education:evidence-based practices for children with special needs and disabilities. (New York: Springer, 2014).

${ }^{25}$ Ainscow, M., Slee, R. \& Best, M. "Editorial: the Salamanca Statement: 25 years" International Journal of Inclusive Education 23 (2019):7-8, 671-676, DOI: 10.1080/13603116.2019.1622800.

${ }^{26}$ Boot, T. \& Ainscow, M. Index for inclusion developing learning and participation in schools. (Bristol (England): Centre for Studies on Inclusive Education, 2002).

27 Carrington, S. B., \& Macarthur, J. Teaching in inclusive school communities. (John Wiley \& Sons Inc, 2012). p. 24. See: Boot, T. \& Ainscow, M. Index for inclusion developing learning and participation in schools. (Bristol (England): Centre for Studies on Inclusive Education, 2002).

28 Thomas, G. "Inclusive schools for an inclusive society". British Journal of Special Education 24, no. 3 (1997): 103-107. Available at https://onlinelibrary.wiley.com/doi/abs/10.1111/14678527.00024. Date accessed on September, $5^{\text {th }} 2019$ at 11.18 p.m.

${ }^{29}$ Carrington, S. B., \& Macarthur, J. Teaching in inclusive school communities. (John Wiley \& Sons Inc, 2012). p. 24. See: Boot, T. \& Ainscow, M. Index for inclusion developing learning and participation in schools. (Bristol (England): Centre for Studies on Inclusive Education, 2002).
} 
community, have global significance, and encourage schools to consider their contribution to a healthy community. Other values include, for example, equality, participation, community, compassion, respect for diversity, and rights. Meanwhile, Booth adds the values of honesty, rights, joy, nonviolence, trust, courage, love, hope or optimism, and beauty. ${ }^{30}$

Starting from the ideas that view the schooling process as training for the realization of a democratic society, ${ }^{31}$ the need for people who live together side by side and educate each other, that a variety of values must be developed in inclusive education, ${ }^{32}$ so it can be concluded that value education is vital in supporting the realization of inclusive education. This idea is in line with the movement of value education and character education that carries the learning of various universal values in schooling. Two out of ten reasons put forward by Lickona, as quoted by Zidniyati about why schools must make clear and wholehearted commitments to teach moral values and develop good character, are that the role of schools as moral educators becomes more critical in times millions of people. ${ }^{33}$ Children receive little moral instruction from parents or less access from religious education centers in childhood. At some point, children must obtain moral examples or the value of character builders from their immediate environment. One other strong reason put forward by Lickona is because "there is no such thing as value-free education." ${ }^{34}$ That is, all education units must teach values. These values are certainly needed for the development of children's learning. Included among these values are through a culture of attitudes that (1) teachers and all adults show in the school environment when behaving to students, (2) culture of attitudes exhibited by schools to

${ }^{30}$ Ibid.

${ }^{31}$ Ainscow, M., Slee, R. \& Best, M. "Editorial: the Salamanca Statement: 25 years" International Journal of Inclusive Education 23 (2019): 7-8, 671-676, DOI: 10.1080/13603116.2019.1622800. See: Carrington, S. B., \& Macarthur, J. Teaching in inclusive school communities. (John Wiley \& Sons Inc, 2012).

${ }^{32}$ Ainscow, M., \& Miles, S. “Making Education for All inclusive: where next?” Prospects, 38, no. 1 (2008): 15-34. Available at https://scholar.google.co.id/scholar?hl=id\&as_sdt=0\%2C5\&q=ainscow+\%26+miles\&btnG=. $\quad$ Data Accessed on September 5 2019 at 5.13 a.m.

${ }^{33}$ Zidniyati, "The implementation of values Comprehensive approach in developing character in an elementary school in banyuwangi (An Observational Report)" Proceeding International Conference on Islamic Education (ICIED) 2, no. 1 (2017): 286-298. Available at https://scholar.google.co.id/scholar?hl=id\&as_sdt=0\%2C5\&q=zidniyati\&btnG= Date Accessed September $6^{\text {th }} 2019$ at 10.00 a.m.

34 Thomas, G. "Inclusive schools for an inclusive society". British Journal of Special Education 24, no. 3 (1997): 103-107. Available at https://onlinelibrary.wiley.com/doi/abs/10.1111/14678527.00024. Date accessed on September, $5^{\text {th }} 2019$ at 11.18 p.m. 
parents, and (3) culture of student attitudes towards all staff at school and others. In this case, Lickona emphasized not to ask, "Should schools teach values?" (Should schools teach grades (character builders)?), But it's better to ask "What values will they teach?" (Which values will be taught?) And "How well will they teach them?" (How well do they teach these values?).

In line with this, Tillman one of the initiators of living values education, states that four basic human needs will direct his life journey, namely: (1) the need to be loved (, to be loved), (2 ) needs to be protected (to be saved), (3) needs to be respected (to be respected), and (4) needs to be cared for. ${ }^{35}$ Based on these four basic needs, the initiators of value education through the living values education program conduct a series of programs which in principle assume that every human being is born with the seeds of virtue, and because of that, in this program emphasizes various ways so that the seeds of goodness can be fertilely cared for. Tillman emphasized that an environment that is capable of directing every child to be able to live and grow with a pleasant atmosphere, then the seeds of goodness, will increasingly lead in a positive direction. At this meeting point, it can be seen that an environment that provides a favorable situation will further develop positive values for every human being. We can see that the inclusive education system also requires the development of value education in schools. The realization of the goal of inclusive education can be achieved when a universal values development program is carried out in schools.

\section{The Implications of Implementing an Inclusive Education System in Primary Schools}

So far, the discussion carried out in this paper has directed us to be able to compile the implications needed in implementing an inclusive education system. Based on various theoretical and practical discussions in several elementary schools as reviewed earlier in other sections of this paper, it appears that what is needed for the realization and success of inclusive education is the application of the value of acceptance and the value of mutual ownership. These values must be developed in the creation of environment and culture in inclusive schools. Strengthening the school policy system is also needed to help realize the goals of inclusion. The curriculum becomes an essential part of carrying out the process

35 Zidniyati, "Penguatan Pendidikan Karakter di Sekolah Dasar di Era Revolusi Industri 4.0." Tarbiyatuna: Kajian Pendidikan Islam 3, no. 1 (2019): 39-55. Available at http://ejournal.iaiibrahimy.ac.id/index.php/tarbiyatuna/article/view/199.Date Accessed September $6^{\text {th }} 2019$ at 10.11. a.m. 
of activities in inclusion programs. To facilitate the collaboration of these three things, Booth and Ainscow propose three dimensions in Index for Inclusion. ${ }^{36}$ Each dimension consists of 2 parts.

The first dimension is the creation of a culture of inclusion, which is divided into 2, namely community development and the establishment of inclusive values. This dimension creates a safe, accepting, collaborating, and stimulating community, where everyone is valued as the foundation for the highest achievement of all. It develops shared inclusive values that are conveyed to all new staff, students, governors, and parents/guardians. Principles and values, in inclusive school culture, guide decisions about policies and practices from time to time in the classroom, so that school development is an ongoing process.

The second dimension is the creation of an inclusive policy, which is divided into two parts, namely developing schools for all and organizing support for diversity. This dimension ensures that inclusion covers all school plans. Policies encourage the participation of students and staff since they joined the school, reaching all students in the area, and minimizing selective pressure. All policies involve a clear change strategy. Support is considered as all activities that increase the capacity of schools to respond to student diversity. All forms of support are developed according to inclusive principles and put together in a single framework.

The third dimension is developing inclusive practices, which are divided into 2 parts, namely orchestrating learning and mobilizing resources. This dimension develops school practices that reflect school culture and inclusive policies. The lessons are made responsive to student diversity. Students are encouraged to be actively involved in all aspects of their education, which refers to their knowledge and experience outside of school. Staff identifies material resources and resources within each other, students, parents/caregivers, and local communities who can be mobilized to support learning and participation.

When looking at the need for a culture of inclusion, inclusion policies, and inclusion practices that contain universal values in schools, there must be support from the stakeholders, namely from the education office. At the very least, policies implemented in

\footnotetext{
${ }^{36}$ Boot, T. \& Ainscow, M. Index for inclusion developing learning and participation in schools. (Bristol (England): Centre for Studies on Inclusive Education, 2002).
} 
inclusive schools will be supported by local education department policy makers. The philosophy of inclusive education is a top priority in this study, especially on the enforcement of inclusive values As affirmed by Ainscow Slee, and Best, ${ }^{37}$ "...that policy is made at all levels of an education system, not least at the school and classroom levels. " That it is necessary to formulate a policy that covers all levels of education. Moreover therefore, still according to Ainscow, Slee, and Best ${ }^{38}$ that, "... the promotion of inclusion is not simply a technical or organizational change - it is a movement in a clear philosophical direction." Which can be interpreted with the affirmation that the application inclusion is not just a technical change or organizational change, but the application of inclusion is a movement at a philosophical level with clear objectives. The inclusive movement thus requires, "...shifts in policy-makers" values and ways of thinking, which enables them to provide a vision of shaping a culture of inclusion, through to significant changes within schools and classrooms. Furthermore, of course, this has to involve the wider community. So it is clear that the implementation of inclusion requires a shift in values and ways of thinking at the level of policymakers, which directs them to provide a vision for shaping an inclusive culture, through significant changes in schooling and in classrooms, of course, and of course, also must involve the wider community. Thus, the analysis of the implementation of inclusive education implementation must involve three dimensions (Ainscow, 2002; Carrington \& Macarthur, 2012: 346), namely culture, policy, and practice. ${ }^{39}$

\section{CONCLUSION}

The nature of implementing an inclusive education system in elementary schools is based on the idea that schooling is a training ground to be part of a democratic society. From several examples of inclusive education practices so far, it illustrates that the practices carried out by education practitioners in six private schools, it appears that each school has a different way of assisting students. The examination system from the local education office, left homework for the inclusion organizer because the level of difficulty of the questions did not match the type of student's specificity. Various obstacles

\footnotetext{
${ }^{37}$ Ainscow, M., Slee, R. \& Best, M. "Editorial: the Salamanca Statement: 25 years". International Journal of Inclusive Education 23 (2019):7-8, 671-676, DOI: 10.1080/13603116.2019.1622800.

${ }^{38}$ Ibid.

${ }^{39}$ Carrington, S. B., \& Macarthur, J. Teaching in inclusive school communities. (John Wiley \& Sons Inc, 2012). p. 24.
} 
experienced by the organizing schools lead us to the need for a shared commitment between the school, parents, and the education office.

As in the practice outlined, some schools have difficulty running the learning process when the perceptions and understandings of parents and teachers do not fit the description given about inclusive education itself. Stakeholders also determine the smoothness of the process of inclusive education, especially related to the rules of admission of students with special needs in public schools and the learning evaluation system. From the existing practices, it is seen that at least if mutual respect and culture are cultivated in a school, even schools whose facilities and infrastructure are incomplete, then children with special needs will be able to feel part of the school community. This condition shows the close relationship between value education and inclusive education.

Future studies can be carried out to look more broadly and in-depth on how to make the main conditions for inclusive education, namely, the value of mutual respect for diversity education can be implemented. It also needs to be studied in-depth, how do so parents and policymakers and teachers in schools have the same, strong perceptions, understandings and commitments for the creation of a culture of inclusion, inclusion policy, and inclusion practices.

\section{REFERENCES}

Anggraeni, Novita \& Sad Dian Utomo. (2018). Pelayanan Publik Bagi Disabilitas: Kajian Praktik Baik dan Inovasi dari Mitra Program Peduli Pilar Disabilitas. Fase 1 (tahun 2015-2016) di Lima Provinsi pada Sektor Pelayanan Publik. (Jakarta: PATTIRO Pusat Telaah dan Informasi Regional). http://pattiro.org/2018/06/pelayanan-publik-bagi-disabilitas-kajian-praktik-baikdan-inovasi-dari-mitra-program-peduli-pilar-disabilitas-fase-1-tahun-2015-2016di-lima-provinsi-pada-sektor-pelayanan-publik/.

Azorín, Cecilia \& Mel Ainscow. (2018). "Guiding Schools on Their Journey Towards Inclusion" International Journal of Inclusive Education, DOI: 10.1080/13603116.2018.1450900.

A., Kearney. (2009). "Barriers to school inclusion: An investigation into the exclusion of disabled students from and within New Zealand schools." Unpublished thesis (Massey University: Palmerston North, New Zealand). Available at https://scholar.google.co.id/scholar?hl=id\&as_sdt=2005\&sciodt $=0 \% 2 \mathrm{C} 5 \&$ cites $=5$ $758551630393361173 \&$ scipsc $=\& q=$ kearney $\% 2 C+A+$ barrier + to + school + inclusion $\underline{\& o q=}$ Date Accessed on September $5^{\text {th }} 2019$ at 5.03 a.m.

Dapodik, as of January, $31^{\text {st }} 2019$. 
Garry, Hornby. (2014). Inclusive special education:evidence-based practices for children with special needs and disabilities. (New York: Springer).

G., Thomas. (1997). "Inclusive schools for an inclusive society". British Journal of Special Education 24, no. 3: 103-107. Available at https://onlinelibrary.wiley.com/doi/abs/10.1111/1467-8527.00024. Date accessed on September, $5^{\text {th }} 2019$ at 11.18 p.m.

M., Ainscow, \& Miles, S. (2008). "Making Education for All inclusive: where next?" Prospects, 38, no. 1: 15-34. Available at https://scholar.google.co.id/scholar?hl=id\&as_sdt=0\%2C5\&q=ainscow+\%26+mil es\&btnG=. Data Accessed on September $5^{\text {th }} 2019$ at 5.13 a.m.

Slee, R., Ainscow, M. \& Best, M. (2019). "Editorial: the Salamanca Statement: 25 years" International Journal of Inclusive Education 23: 7-8, 671-676, DOI: 10.1080/13603116.2019.1622800.

Sudarno, Rohidin \& Sad Dian Utomo. (2018). Inovasi Pendataan Disabilitas: Inovasi dan Praktik Baik Mitra Program Peduli Disabilitas Fase 1 di Enam Provinsi. (Jakarta: PATTIRO Pusat Telaah dan Informasi Regional). http://pattiro.org/2018/06/inovasi-pendataan-disabilitas-kajian-dan-praktik-baikmitra-program-peduli-disabilitas-fase-1-di-enam-provinsi/.

S. B., Carrington \& Macarthur, J. (2012). Teaching in inclusive school communities. (John Wiley \& Sons Inc).

T., Boot \& Ainscow, M. (2002). Index for inclusion developing learning and participation in schools. (Bristol (England): Centre for Studies on Inclusive Education).

Utomo, Sad Dian, et.al. (2018). Policy Paper: Mewujudkan Pembangunan Inklusif Disabilitas: Rekomendasi Kebijakan untuk Penyusunan RPJMN 2020-2024. http://pattiro.org/2018/11/policy-paper-mewujudkan-pembangunan-inklusifdisabilitas-rekomendasi-kebijakan-untuk-penyusunan-rpjmn-2020-2024/.

World Economic Forum. (2017). The Inclusive Growth and Development Report.

Zidniyati. (2017). "The implementation of values Comprehensive approach in developing character in an elementary school in banyuwangi (An Observational Report)" Proceeding International Conference on Islamic Education (ICIED) 2, no. 1 2 286-298. Available at https://scholar.google.co.id/scholar?hl=id\&as_sdt=0\%2C5\&q=zidniyati\&btnG= Date Accessed September 6 2019 at 10.00 a.m.

Zidniyati. (2019). "Penguatan Pendidikan Karakter di Sekolah Dasar di Era Revolusi Industri 4.0." Tarbiyatuna: Kajian Pendidikan Islam 3, no. 1: 39-55. Available at http://ejournal.iaiibrahimy.ac.id/index.php/tarbiyatuna/article/view/199.Date Accessed September $6^{\text {th }} 2019$ at 10.11. a.m. 
Reconstructing The Nature of Inclusive School System ... 